\title{
Derived Peripheral Blood Mononuclear
} Cell

National Cancer Institute

\section{Source}

National Cancer Institute. Derived Peripheral Blood Mononuclear Cell. NCI Thesaurus.

Code C138972.

Mononuclear cells collected from peripheral blood. 